Research Paper

\title{
Seasonal variation on the presence of adenoviruses in stools from non-diarrheic patients
}

\author{
Michele Regina Vetter, Rodrigo Staggemeier, Andréia Dalla Vecchia, Andréia Henzel, \\ Caroline Rigotto, Fernando Rosado Spilki
}

Laboratório de Microbiologia Molecular, Instituto de Ciências da Saúde, Universidade Feevale, Novo Hamburgo, RS, Brazil.

Submitted: September 2, 2014; Approved: November 16, 2014.

\begin{abstract}
Human adenoviruses (HAdV), members of the Adenoviridae family, are excreted through the fecal route and may be present in the feces of humans consuming contaminated food or water. The presence of HAdV from different serotypes in the feces of healthy individuals was already reported using conventional polymerase chain reaction; however, real-time PCR (qPCR) may reveal not only the rates of detection as well as demonstrate the viral loads excreted by healthy persons. Aiming to identify and characterize the presence of adenoviruses in stool samples, 147 fecal samples from patients with no records of diarrhea were analyzed ( 74 from winter season and 73 from summer) by Real-Time PCR (qPCR) assay and conventional PCR. HAdV genome was present in 43.8\% (32/73) of stools samples collected during summer season and $21.6 \%$ (16/74) during winter. The rate of detection of genomic copies (gc) ranged from $4.04 \times 10^{2}$ to $6.72 \times 10^{5} \mathrm{gc} / \mathrm{g}$ of feces among the 147 samples analyzed, of which the ranged of genomic copies of DNA HAdV was major in summer. All samples were negative when tested for rotaviruses (RV) and noroviruses (NoV) by PCR conventional and qPCR respectively. HAdV is excreted constantly by infected individuals in the absence of clinical signs and the occurrence may vary seasonally.
\end{abstract}

Key words: HAdV, stool samples, qPCR, healthy individuals.

\section{Introduction}

Human adenovirus (HAdV) is a double stranded DNA virus, non-enveloped, that belongs to the Mastadenovirus genus within Adenoviridae family (Wold and Horwitz, 2007). The infections caused by HAdVs may be asymptomatic, or may induce common diseases such as respiratory distress, gastroenteritis and hemorrhagic cystitis (Lenaerts et al., 2008). HAdV from the respiratory types (group C) may also be found in feces, probably as a result of swallowing of upper respiratory tract secretions, although not replicating or causing disease in the gastrointestinal tract (Lenaerts et al., 2008). The occurrence of adenoviruses from different tracts in feces may be related to the relatively high frequency of these viruses in environmental matrices (Barardi et al., 2012).
Rotavirus (RV), adenovirus (AdV) and norovirus $(\mathrm{NoV})$ are often related with both diarrhea and subclinical infections (Boccia et al., 2002; Lenaerts et al., 2008; Tate et al., 2010). These viruses are shed in the feces of infected (symptomatic and asymptomatic) individuals, and acquired through the fecal-oral route by the consumption of contaminated water, food, direct contact and aerosols (Barardi et al., 2012). The enteric viruses are a special concern in public health due to their wide distribution, rapid transmission, high prevalence, and resistance under environmental conditions (Barardi et al., 2012).

Human norovirus (NoV) is a single stranded RNA virus, non-enveloped that belongs to the Norovirus genus from the Caliciviridae family (Green et al., 2000). NoVs are classified in five genogroup (GI to GV), in which GI, GII and GIV most often are detected in human beings (Morillo and Timenetsky, 2011; Fioretti et al., 2014); but 
GII is the most frequently found (Green et al., 2000). NoVs are nowadays the main etiological cause of viral gastroenteritis outbreaks in humans and the excretion by nondiarrheic individuals was not reported (Boccia et al., 2002; Parshionikar et al., 2003). Adenoviruses are transmitted person-to-person, by fecal-oral route and contaminated water and food (Boccia et al., 2002; Parshionikar et al., 2003). NoVs are excreted in high numbers of infective viral particles by infected patients, the risk of infection is higher for individuals in close contact and the excretion is longlasting after clinical recovery, which results in major outbreaks when in closed premises like cruise ships, kind gardens and schools (Lopman et al., 2004).

Rotaviruses (RVs) are segmented double stranded RNA viruses, non-enveloped, from the Rotavirus genus and Reoviridae family (Tate et al., 2010). The infection by $\mathrm{RV}$ s is characterized by a short incubation period, normally one to three days, and the clinical signs may range from asymptomatic infections (especially in immune adults) to severe gastroenteritis in children and immunocompromised patients. RVs were estimated to cause over 400,000 deaths annually before the introduction of vaccination in children aged less than 5 years in developing countries, and are responsible for over 500,000 visits to medical practitioners annually in the USA alone (Tate et al., 2010).

$\mathrm{RV}$ and NoV are also detected in asymptomatic patients (Enserink et al., 2014), but previous studies using conventional PCR have confirmed decades ago that HAdVs are more consistently found on the stools of non-diarrheic individuals than RV and NoV (Allard et al., 1992). However, it is now important to conduct again studies on monitoring enteric viruses in non-diarrheic patients with more reliable techniques (Enserink et al., 2014). The major part of the studies regarding the presence of enteric viruses are based on stool testing of symptomatic individuals, while probably a far larger number of gastrointestinal infections appear sporadically in feces and possibly runs asymptomatically (Enserink et al., 2014).

This study aims to identify the presence and quantification of HAdVs in stool samples submitted for routine parasitological monitoring from adults, since these individuals may be temporary asymptomatic carriers of these viral infections. The study was conducted in samples from nondiarrheic patients in Southern Brazil, during winter and summer seasons, using quantitative real-time polymerase chain reaction (qPCR) for detection of HAdV from the group $\mathrm{C}$, mainly associated with respiratory diseases, as an effort to better understand why these viruses are so frequently found contaminating water (Barardi et al., 2012). Additionally, the presence of NoV and RV, typical enteric viruses, was assessed by conventional PCR.

\section{Material and Methods}

\section{Source of samples}

The sample size was calculated based on the frequencies of HAdV in stools in previous reports (Lenaerts et al., 2008). The 147 stool samples evaluated in the present study were collected for routine parasitological monitoring from adult individuals ageing from 20 to 50 years old, in a clinical laboratory from Esteio city, southern Brazil. All samples were obtained randomly without relation to diarrheic cases, allotted into adults from both genders and collection by two seasons: 74 samples were collected in winter of 2011 (June, July and August) and 73 during of the summer of 2012 (December, January and February). The stool samples were collected in plastic vials of $1.5 \mathrm{~mL}$, maintained under refrigeration for transportation and after kept to $-80{ }^{\circ} \mathrm{C}$ until processing.

The work was approved by the Universidade Feevale - Ethics Committee \# 2.12.01.08.1035. All procedures were made according to ethical premises and Brazilian national regulations.

\section{Nucleic acid extraction and cDNA synthesis}

For each stool sample, $1 \mathrm{~mL}$ of Eagle's minimum essential medium (E-MEM, Nutricell; $\mathrm{pH} 7.4$ ) was added to $1 \mathrm{~g}$ of feces. The solution was homogenized by vortex for $1 \mathrm{~min}$ and then centrifuged at $16,000 \times \mathrm{g}$ for $10 \mathrm{~min}$. The supernatant was used for DNA/RNA extraction. The nucleic acid were extracted from $400 \mu \mathrm{L}$ of fecal suspensions by the commercial kit RTP DNA/RNA Virus Mini Kit (Stratec ${ }^{\circledR}$, Germany), following manufacturer's recommendations. The nucleic acids obtained were eluted in $60 \mu \mathrm{L}$ of TE buffer and stored until $-80{ }^{\circ} \mathrm{C}$ until use. Putative viral RNA molecules were submitted to cDNA synthesis using High-Capacity cDNA Reverse Transcription (RT) kit [Applied Biosystems ${ }^{\circledR}$, USA] following manufacturer's instructions. The cDNA was synthesized in $20 \mu \mathrm{L}$ of total solution containing the following: $2 \mu \mathrm{L}$ of RNA (approximately $100 \mathrm{ng}$ ), $100 \mathrm{ng}$ of random primers, $10 \mathrm{X}$ buffer from RT, $25 \mathrm{mM} \mathrm{MgCl}_{2}, 10 \mathrm{mM}$ dNTPs, 0.1 Mm DTT, $40 \mathrm{U}$ RNaseOUT (Invitrogen ${ }^{\circledR}$, USA) and 200U reverse transcriptase enzyme. The solution was incubated at $25^{\circ} \mathrm{C}$ for $10 \mathrm{~min}$, after $120 \mathrm{~min}$ at $37^{\circ} \mathrm{C}$ and then left to a final step of 5 min at $85^{\circ} \mathrm{C}$. The cDNA was stored at $-80^{\circ} \mathrm{C}$ until further processing.

\section{Real Time-polymerase chain of reaction for HAdV}

Oligonucleotides for hexon gene of HAdV (VTB2-HAdVCf 5'-GAGACGTACTTCAGCCTGAAT3 ' and VTB2-HAdVCr 5'-GATGAACCGCAGCGTCAA3') were used (20 pmol). Detection of HAdVs was performed by quantitative real time-polymerase chain reaction (qPCR) with kit commercial Platinum ${ }^{\circledR} S Y B R^{\circledR}$ Green qPCR SuperMix-UDG (Invitrogen ${ }^{\circledR}$, USA), diluted according manufacturer's instructions. The final reaction volume 
was of $25 \mu \mathrm{L}: 5 \mu \mathrm{L}$ of DNA extracted, $20 \mathrm{pM}$ of each primer, $12.5 \mu \mathrm{L}$ of Supermix SYBR ${ }^{\circledR}$ Green qPCR (Platinum ${ }^{\circledR}$ Taq DNA polymerase, SYBR ${ }^{\circledR}$ Green I Dye, TRis$\mathrm{HCl}, \mathrm{KCl}, 6 \mathrm{mM} \mathrm{MgCl}$, $400 \mu \mathrm{M}$ dGTP, $400 \mu \mathrm{M}$ dATP, $400 \mu \mathrm{M}$ dCTP, $800 \mu \mathrm{M}$ dUTP, uracil DNA glycosylase) and $5.5 \mu \mathrm{L}$ of DNAse/RNAse free water $\left(\right.$ MilliQ ${ }^{\circledR}$ Direct 8 water system). The qPCR was carried out in an $i Q 5$ Real-Time PCR Detection System Thermocycler (Bio-Rad Laboratories, USA) and the results analyzed using $i Q 5$ optical system, version 2.1 software. The reaction steps were: $95^{\circ} \mathrm{C}$ for $10 \mathrm{~min}$, followed by 40 cycles of one step at $95^{\circ} \mathrm{C}$ for $20 \mathrm{~s}$, combined to an annealing/extension step at $55^{\circ} \mathrm{C}$ for $1 \mathrm{~min}$. The "no template controls" (NTC) and negative controls (sterile water) were used in each run to examine for any cross-contaminations between samples. Melting curve analysis was performed using High Resolution Melting denaturation (HRM) to check the specificity of amplicons (consecutive $0.5^{\circ} \mathrm{C}$ melting steps from 55 to $95{ }^{\circ} \mathrm{C}$ ).

\section{Touch down PCR for rotavirus and norovirus}

Molecular detection for RV of different species - PCR Touch Down for the partial amplification of the VP6 gene was performed with the following primers: ROTAFEEVALE-F 5'- GATGTCCTGTACTCCTTGT-3' and ROTAFEEVALE-R 5' - GGTAGATTACCAATTCC TCC - 3'. PCR reactions were performed GoTaq Green Master Mix (Promega). The final volume of PCR reactions were of $50 \mu \mathrm{L}$, containing $25 \mu \mathrm{L}$ of mix of PCR, $18 \mathrm{uL}$ of DNase/RNase free water, $1 \mu \mathrm{L}$ of each primer (20pmol) $5 \mu \mathrm{L}$ of cDNA (100 ng approximately). The PCR conditions used were as follows: $94{ }^{\circ} \mathrm{C}$ for $5 \mathrm{~min}$, followed by 40 cycles at $94{ }^{\circ} \mathrm{C}$ for $1 \mathrm{~min}, 56^{\circ} \mathrm{C}$ for $30 \mathrm{~s}$ (decreasing $0.5{ }^{\circ} \mathrm{C}$ each step, touchdown), $72{ }^{\circ} \mathrm{C}$ for $1 \mathrm{~min}$ and a final extension of $7 \mathrm{~min}$ at $72{ }^{\circ} \mathrm{C}$. PCR products were electrophoresed in $1.5 \%$ agarose gel, with fluorescent SYBRSafe ${ }^{\circledR} 10.000 \mathrm{X}$ (Invitrogen ${ }^{\circledR}$, USA) staining and visualized under UV light.

For NoVs, previously reported primers were used, namely COG2 Forward 5'-CARGARBCNATGTTYAGR TGGATGAG - 3' and Reverse 5'-TCGACGCCATCTT CATTCACA - 3' (Kageyama et al., 2003). The mixture for reactions was: $12.5 \mu \mathrm{L}$ was of mix reaction (Platinum Sybr ${ }^{\circledR}$ Green qPCR SuperMix-UDG, Invitrogen), $5.5 \mu \mathrm{L}$ of water DNase/RNase free, $1 \mu \mathrm{L}$ of each primer $(20 \mathrm{pmoL})$ and $5 \mu \mathrm{L}$ f each sample. The touchdown-PCR consisted of an initial step at $94^{\circ} \mathrm{C}$ for $2 \mathrm{~min}$, following of 40 cycles for $94^{\circ} \mathrm{C}$ for $1 \mathrm{~min}$ at denaturation, 1 min starting at $59^{\circ} \mathrm{C}$ (decreasing $0.5^{\circ} \mathrm{C}$ each step), $72{ }^{\circ} \mathrm{C}$ for $1 \mathrm{~min}$ and a final extension step of $7 \mathrm{~min}$ at $72{ }^{\circ} \mathrm{C}$. The analytic sensibility of $102 \mathrm{gc} / \mu \mathrm{L}$. As a positive control, naturally genogroup GII NoV-infected were used. This positive sample was kindly provided by Dra. Suelen Paesi from the Universidade de Caxias do Sul, Brazil.

\section{Results}

From the 147 stool samples analyzed in the present survey, only HAdV genome was found, none was positive for RV or NoV.

From the stools samples analyzed, 43.8\% (32/73) were positive for HAdV for the summer season and $21.6 \%$ (16/74) from those collected in winter, totalizing 32.6\% positive samples (48/147). Regarding HAdVs loads, the rate of detection ranged from $4.04 \times 10^{2}$ to $6.72 \times 10^{5} \mathrm{gc}$ per gram of feces. In the summer, the variation was from $2.19 \times 10^{3}$ to $6.72 \times 10^{5} \mathrm{gc} / \mathrm{g}$ of feces (average $1.43 \times 10^{4} \mathrm{gc} / \mathrm{g}$ of feces) and in the winter $4.04 \times 10^{2}$ to $1.93 \times 10^{5} \mathrm{gc} / \mathrm{g}$ of feces (average $4.01 \times 10^{3} \mathrm{gc} / \mathrm{g}$ of feces).

\section{Discussion}

Human adenovirus (HAdV) is one of the pathogens responsible for viral respiratory diseases and gastroenteritis among infant and children in developed and developing countries. In the present study, HAdV genomes were present in $32.6 \%$ of 147 stool samples analyzed from patients without symptoms of diarrhea during summer and winter season in Esteio, Rio Grande do Sul, Brazil. Results like these are also related in Belem city, Pará/Brazil, which reports the presence of HAdVs all year round (Muller et al., 2010). RV and NoV were absent on the samples analyzed.

The rate of detection observed in this study was considered high when compared with previous reports, since the patients analyzed were non-diarrheic adults. It is also noticeable that primers used are targeted to the detection of respiratory HAdV-C (Wolf et al., 2010), thus these adenoviruses detected might be only part of the excreta of these individuals, since no replication of $\mathrm{HAdV}-\mathrm{C}$ is expected in the gut. In one study performed in Sweden with stool samples, HAdV was detected by PCR in $18 \%$ of 50 healthy adults and in $25 \%$ of 50 adults with clinical signs of gastroenteritis (Allard et al., 1992). In pediatric hospitalized patients, boys and girls from 0-15 years old, with acute gastroenteritis in Douala, Cameroon, 25 cases from liquid (diarrheic) and 40 cases from solid (non diarrheic) feces were analyzed; the rate of detection of HAdV was of $43.1 \%$ varying among the age groups (Mogtomo et al., 2008). In Khartoum state, Sudan, from 198 adult patients with diarrhea, 6 (3.1\%) were HAdV positive (Elhag et al., 2013). In a prospective 1-year study in Sweden, adenoviruses were detected in $13 \%$ of stool samples from children with gastroenteritis (Uhnoo et al., 1986).

Another important epidemiological feature observed in the present study was the different rates of detection in summer $v s$. winter, $43.8 \%$ to $21.6 \%$ respectively; furthermore the viral load was also higher in summer, ranging from $2.19 \times 10^{3}$ to $6.72 \times 10^{5} \mathrm{gc} / \mathrm{g}$ of feces. These results may be related with several aspects, including an unknown feature of the biology of infection in adults, as well as, more likely, the greater intake of water during summer season, 
considering that the drinking water in Brazil is not monitored for viral contamination. The seasonal variation on the shedding of adenovirus seems to be dependent on the geographic region analyzed and the presence of clinical manifestations. In a study performed in Iran, children under 6 years old presented HAdV in stools during the autumn and winter months whether all samples were negative during spring and summer (Hamedi et al., 2010).

As a concluding remark, the results presented here showed that HAdVs are shed constantly by asymptomatic humans in rates and viral loads that may vary seasonally. This may have consequences both for the interpretation of laboratory diagnosis and for the use of HAdVs as markers of fecal contamination of environmental matrices.

\section{Acknowledgments}

This work was supported by the Fundação de Amparo à Pesquisa do Estado do Rio Grande do Sul (FAPERGS, Brazil), Coordenação de Aperfeiçoamento de Pessoal de Nível Superior (CAPES, Brazil), and Brazilian National Research Council (CNPq). FRS is a CNPq research fellow.

\section{References}

Allard A, Albinsson B, Wadell G (1992) Detection of adenoviruses in stools from healthy persons and patients with diarrhea by two-step polymerase chain reaction. J Med Virol 37:569-577.

Barardi CRM, Viancelli A, Rigotto C et al. (2012) Monitoring viruses in environmental samples. Intern J Environ Sci Eng Res 3:62-79.

Boccia D, Tozzi AE, Cotter B et al. (2002) Waterborne outbreak of Norwalk-like virus gastroenteritis at a tourist resort, Italy. Emerg Infect Dis 8:563-568.

Elhag WI, Saeed HA, Omer el FE et al. (2013) Prevalence of rotavirus and adenovirus associated with diarrhea among displaced communities in Khartoum, Sudan. BMC Infect Dis 13:1-6.

Enserink R, Scholts R, Bruijning-Verhagen P et al. (2014) High detection rates of enteropathogens in asymptomatic children attending day care. PLoS One 9:e89496.
Fioretti JM, Bello G, Rocha MS et al. (2014) Temporal dynamics of norovirus GII.4 variants in Brazil between 2004 and 2012. PLoS One 9:e92988.

Green KY, Ando T, Balayan MS et al. (2000) Taxonomy of the caliciviruses. J Infect Dis 181:322-330.

Hamedi A, Sadeghian A, Syedi J (2010) Incidence of Adenovirus diarrhea in children under 6 years referred to the pediatric emergency and clinic of Ghaem Hospital, Mashhad, Iran. Iran J Pediatric Soc 2:70-74.

Kageyama T, Kojima S, Shinohara M et al. (2003) Broadly reactive and highly sensitive assay for Norwalk-like viruses based on real-time quantitative reverse transcription-PCR. J Clin Microbiol 41:1548-1557.

Lenaerts L, De Clercq E, Naesens L (2008) Clinical features and treatment of adenovirus infections. Rev Med Virol 8:357374.

Lopman B, Vennema H, Kohli E et al. (2004) Increase in viral gastroenteritis outbreaks in Europe and epidemic spread of new norovirus variant. Lancet 363:682-688.

Mogtomo MLK, Ghogomu HMN, Kamdjoum SIT et al. (2008) Incidence of adenovirus detected by immunoenzymatic assay from children hospitalized with acute gastroenteritis in Douala, Cameroon. Inter J Biol Chem Sci 2:220-223.

Morillo SG, Timenetsky MCST (2011) Norovirus: an overview. Rev Assoc Med Bras 57:453-458.

Muller ECA, Morais MAAM, Gabbay YB et al. (2010) Ocorrência de adenovírus em crianças com gastrenterite aguda grave na Cidade de Belém, Pará, Brasil. Rev Pan Amaz Saúde 1:43-47.

Parshionikar SU, Willian-True S, Fout GS et al. (2003) Waterborne outbreak of gastroenteritis associated with a norovirus. App Environ Microbiol 69:5263-5268.

Tate JE, Patel MM, Steele AD et al. (2010) Global impact of rotavirus vaccines. Expert Rev Vaccines 9:395-407.

Uhnoo I, Wadell G, Svensson L et al. (1986) Aetiology and epidemiology of acute gastro-enteritis in Swedish children. J Infec 13:79-80.

Wold WSM, Horwitz MS (2007) Adenoviruses. In: Knipe DM, Howley PM (eds) Fields Virology. fifth edition. Lippincott Willians \& Wilkins, Philadelphia, pp 2396-2436.

Wolf S, Hewitt J, Greening GE (2010) Viral multiplex quantitative PCR assays for tracking sources of fecal contamination. Appl Environ Microbiol 76:1388-1394.

Associate Editor: Maurício Lacerda Nogueira

All the content of the journal, except where otherwise noted, is licensed under a Creative Commons License CC BY-NC. 